University of Nebraska - Lincoln

DigitalCommons@University of Nebraska - Lincoln

$12-2019$

\title{
The Kaiparowits Puebloans: Kayentan or Virgin Branch Migrants?
}

Phil R. Geib

Follow this and additional works at: https://digitalcommons.unl.edu/anthropologyfacpub

Part of the Archaeological Anthropology Commons, and the Social and Cultural Anthropology Commons

This Article is brought to you for free and open access by the Anthropology, Department of at DigitalCommons@University of Nebraska - Lincoln. It has been accepted for inclusion in Anthropology Faculty Publications by an authorized administrator of DigitalCommons@University of Nebraska - Lincoln. 


\title{
The Kaiparowits Puebloans: Kayentan or Virgin Branch Migrants?
}

\author{
Phil R. Geib \\ Department of Anthropology, University of Nebraska-Lincoln \\ pgeib2@unl.edu
}

\begin{abstract}
More than 50 years ago archaeologists identified a high-density of small Puebloan habitations on the Kaiparowits Plateau in southern Utah. Analysis of pottery from these habitations by James Gunnerson and Florence Lister resulted in conflicting interpretations of cultural affiliation. Gunnerson argued for a Virgin affiliation whereas Lister argued for a Kayentan affiliation. Lister's interpretation triumphed and the Puebloan occupation of the Kaiparowits was attributed to a migration of Kayenta people from the south during the late Pueblo II period. A review of architectural and artifactual evidence fails to support a Kayentan migration. An expansion of Puebloan groups from the west and southwest better accords with the archaeological record on the Kaiparowits Plateau.
\end{abstract}

\section{Resumen}

Hace más de 50 años, arqueólogos identificaron una alta densidad de pequeñas habitaciones Puebloan en la Meseta de Kaiparowits en el sur de Utah. La análisis de la cerámica de estas habitaciones por James Gunnerson y Florence Lister resultó en interpretaciones contradictorias de la afiliación cultural. Gunnerson abogó por una affilición Virgin mientras que Lister abogó por una affilición Kayentan. La interpretación de Lister triunfó y la ocupación Puebloan del Kaiparowits fue atribuyó a una migración de gente Kayenta desde el sur durante el periódo tarde Pueblo II. Una revisión de la evidencia sobre la arquitectónica y los artefactos no respalda una migración Kayentan. Una expansion de los grupos Puebloan desde el oeste y suroeste se adhiere mejor con el registro arqueológico en la Meseta de Kaiparowits.

Published in Kiva, Vol. 85 No. 4 (December 2019), pp 434-450

DOI: $10.1080 / 00231940.2019 .1690317$

Copyright (C) 2019 Arizona Archaeological and Historical Society; published by Taylor \& Francis. Used by permission. 
Keywords: Migration, cultural affiliation, Kayenta Branch, Virgin Branch, Fremont, Kaiparowits Plateau, Fiftymile Mountain

Since the Glen Canyon Project of the late 1950s and early 1960s (Jennings 1966), the Kaiparowits Plateau in southern Utah has been viewed as a boundary zone of sorts between at least three Formative cultures that impinged from different sides (Figure 1). North of the plateau were the Fremont; south, across the Colorado River, were the Kayenta Puebloans; and west were the Virgin Branch Puebloans. Ceramics were a heavily weighted identity marker. As often happens, disagreement erupted as to which people could be equated with the pottery.

This debate goes back 60 years to when University of Utah crews surveyed and excavated on Fiftymile Mountain, the highest and best watered portion of the Kaiparowits Plateau. A prehistoric Puebloan presence on this plateau was known about since at least the 1920 s (e.g., Kluckhorn [1993:229-230] made reference to numerous Puebloan ruins on the mesa), but it was not until the Glen Canyon Project of the late 1950 s and early 1960 s that adequate documentation

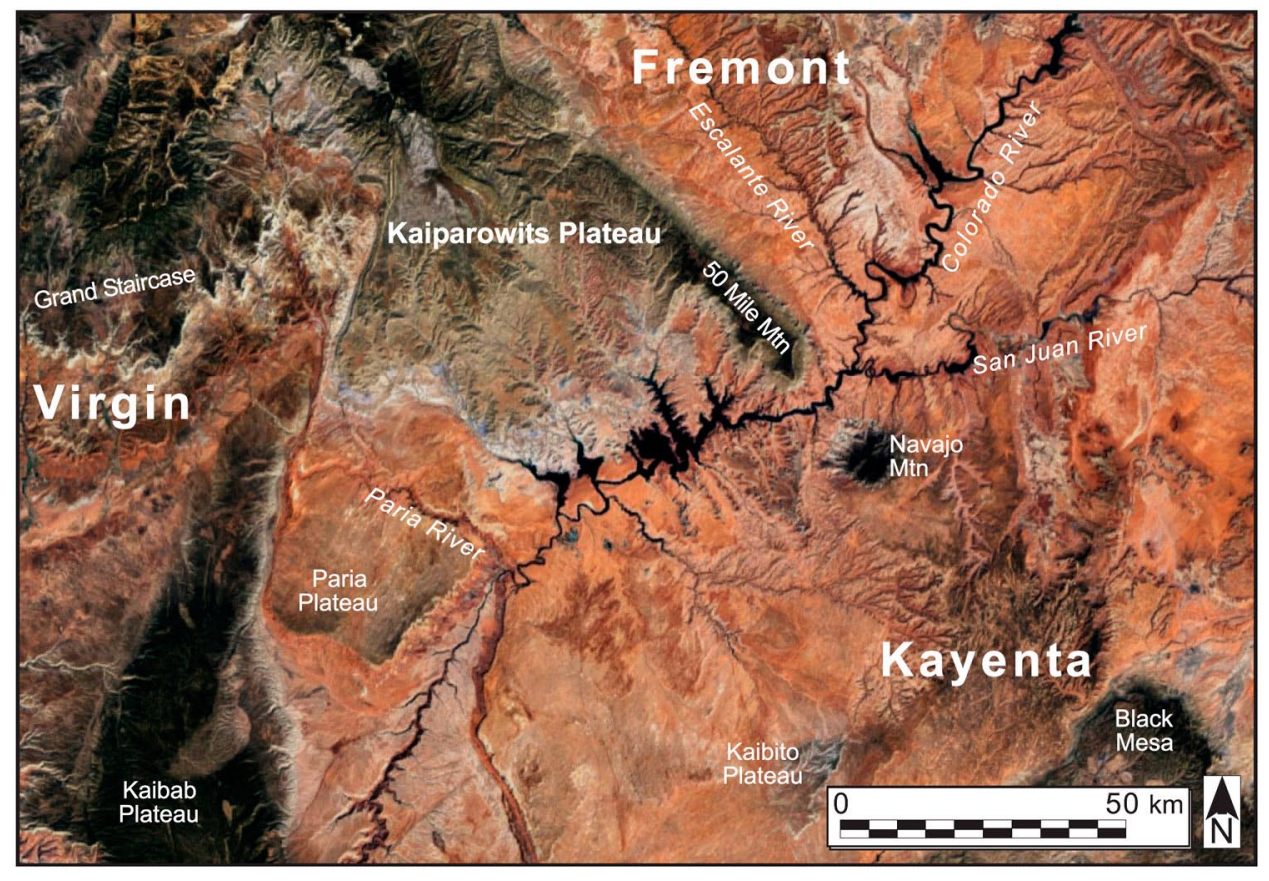

Figure 1. Aerial image of southeast Utah and northeast Arizona centered on the Kaiparowits Plateau and showing the three archaeological cultures of the ceramic period whose remains are found on and around this physiographic feature. 
of this occupation was published (Aikens 1962, 1963; Fowler and Aikens 1963; Gunnerson 1959a). This work revealed a substantial density of small Puebloan farmsteads, single or extended family in size, that derived from a narrow slice of time corresponding with what today we would refer to as the late Pueblo II and early Pueblo III period (ca. AD 1100-1200). James Gunnerson and Florence Lister held different opinions about the cultural affiliation of this Puebloan occupation.

According to Gunnerson, who conducted the first extensive survey on Fiftymile Mountain,

the great preponderance of Virgin Series Black-on-gray sherds, as compared to sherds of Tusayan White, Tsegi Orange, and San Juan Red wares, and the probable Virgin affiliation of most of the corrugated and plain gray pottery, justifies the assignment of the Puebloan sites on the Kaiparowits to the Virgin branch rather than to the Kayenta branch proper. (Gunnerson 1959a:36o, emphasis added)

Since there was no real evidence for a local Puebloan developmental sequence on the Kaiparowits Plateau, the implication was that the builders of those small Puebloan farmsteads had moved to Kaiparowits from out of the Virgin region, which lay to the west.

In contrast, Lister saw the Puebloan presence on the Kaiparowits as a direct migration of Kayenta people from the south out of northeastern Arizona. She laid out this scenario in 1964 based on her analysis of sherds recovered by the excavations of Fowler and Aikens (1963) on Fiftymile Mountain. Lister envisioned parties of Kayenta Puebloans migrating "north and west," including a "sizable force" pushing up the Escalante drainage and "around and up the Kaiparowits Plateau" (1964:77). The pottery they left behind on Fiftymile Mountain, according to Lister, were plain wares dominated by Tusayan Gray Ware, Tsegi series, and Tusayan White Ware, Kayenta Series (Fowler and Aikens 1963:46-48). Fowler and Aikens accepted Lister's pottery-based interpretation and likewise concluded that "the evidence of the ceramic complex shows the primary occupancy of the plateau to have been the result of a direct northward extension of Kayenta culture bearers from the Tsegi Canyon region of northern Arizona" (Fowler and Aikens 1963:8). In terms of peoples 
and population movements, Lister contrasted her viewpoint with that of Gunnerson as follows:

[Gunnerson] would have Kaiparowits occupation resulting from movements of Kayenta peoples from the west and would see no contact between the Kaiparowits population and the Fremont.We see Kayenta people migrating directly to the Kaiparowits [from northern Arizona], undergoing slight change because of local conditions, and coming into direct association with the Fremont (Lister 1964:75).

Jesse Jennings amplified Lister's notion of a Kayenta migration in his summary report of the Glen Canyon Project: "the Kayenta crossed the Glen Canyon and followed up the Escalante River and Boulder Creek to establish a long communication line, and a large distant outpost [the Coombs site] deep in Fremont country. They also dominated the Kaiparowits [Plateau]" (Jennings 1966:35). Later in the same report he observes, "the best example of Kayenta thrust in the northern part of the Glen Canyon area is the Coombs site; Kayenta control of the entire Kaiparowits seems equally clear" (Jennings 1966:55).

Jennings and Lister had the last word and the Kayenta migration became an established fact, at least for a while. Doubts in this interpretation started to be voiced initially by J. Richard Ambler in the early 1980 s in the context of a Northern Arizona University contract project for survey and test excavations in the Glen Canyon National Recreation Area. These doubts were elaborated upon by Helen Fairley who presented them at an SAA symposium on the 40th anniversary of the start of the Glen Canyon Project (Fairley 1997). The following year, in 1998, I began directing a large sample survey of the Kaiparowits Plateau for the Navajo Nation Archaeology Department within the then newly established Grand Staircase-Escalante National Monument. This project cemented my belief that Ambler and Fairley were right to question the Kayenta migration account. On this project, Navajo Nation archaeologists surveyed over 17,000 acres and recorded 710 sites (Geib et al. 2001). During the second year (2000), we examined sample units in an area called Collet Top, which lies just beyond the northwestern terminus of Fiftymile Mountain (Figure 2). McFadden (2000:165) noted that University of Utah's survey on Fiftymile Mountain 


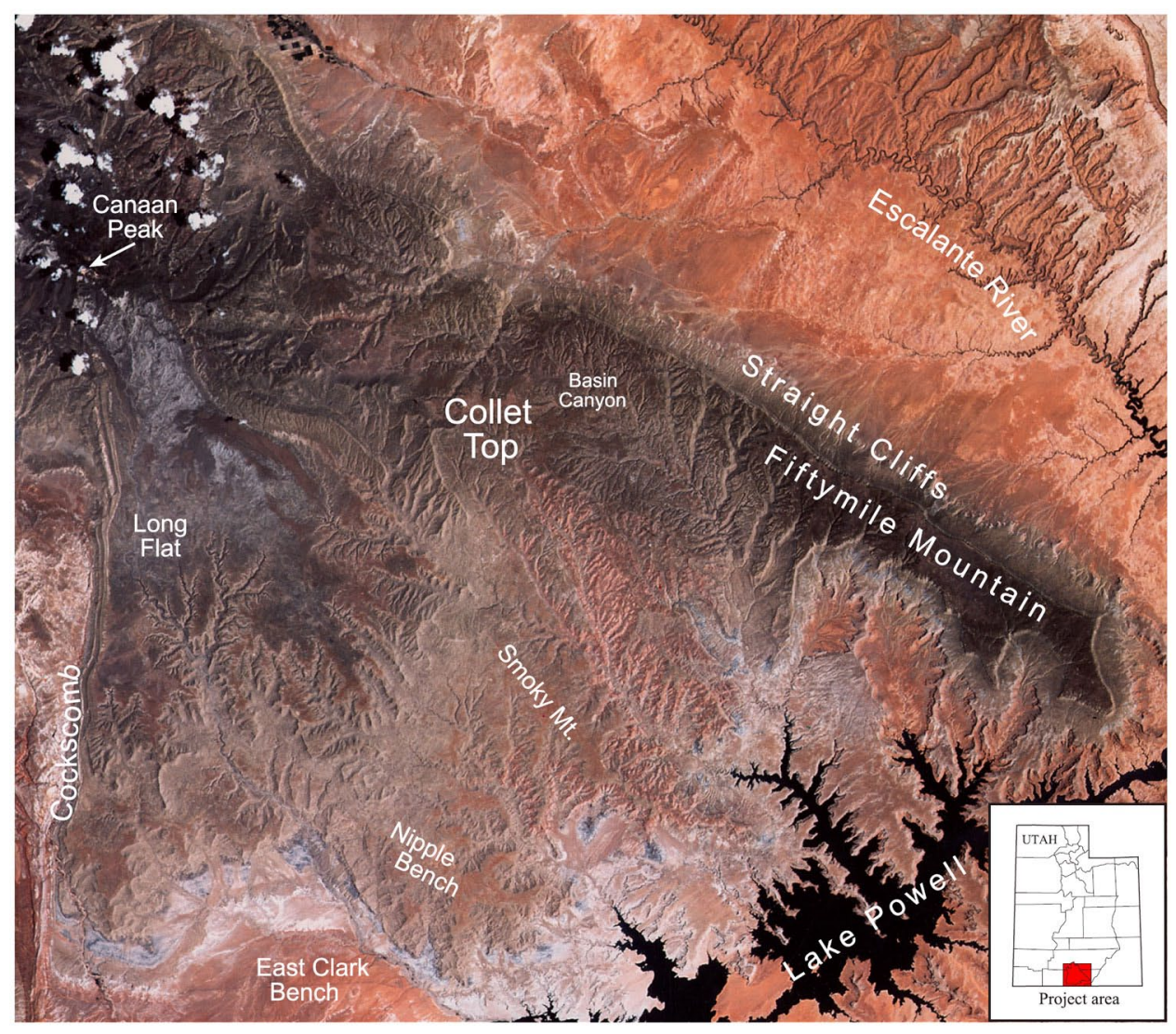

Figure 2. The Kaiparowits Plateau as seen in a Landsat 5 Satellite Thematic Mapper image with 30 mground resolution. The Collet Top study area lies beyond the northwest terminus of Fiftymile Mountain, which ends at Basin Canyon.

ended at Basin Canyon on the north because from that point to Collet Top there are no springs and very little arable land. The Collet Top locality, however, is an exception and does have deep soils, springs [and] adequate precipitation.

If you were a Puebloan looking to establish a farmstead in the closest next-best environment to Fiftymile, Collet Top is the place. This small benchland of about 20 square miles appears well suited to dry farming in non-drought years. Aside from rather numerous seeps/springs its elevational setting between 6000 and 6500 feet is the same as a zone of high residential site density "suitable for dry-farm agriculture" that McFadden (2000:16) observed in the Grand Staircase. In effect, Collet Top is a microcosm of Fiftymile Mountain, albeit at a slightly lower elevation. 
Within five randomly chosen quarter-sections on Collet Top, Navajo Nation archaeologists recorded 55 ceramic period sites. Half of these had structures that ranged in size from 1 to 10 rooms. This is similar to the dense concentration of ceramic period sites on Fiftymile Mountain that Fowler and Aikens (1963) documented in the early 1960 . Pottery types from the Collet Top sites indicated that 38 of the 55 ceramic period sites were Puebloan in cultural affiliation. Given the Kayenta migration that I had learned about early in my career, I expected the Collet Top Puebloan remains to match what I had come to know quite well from what was by then over 20 years of work in the Kayenta region. This wasn't the case. Thus, I pondered: Who were these people? Where had they originated? These simple, basic questions are the ones considered in this paper.

\section{Why Migration?}

Some might wonder why I or others think that the creators of the sites with Puebloan ceramics came from somewhere else rather than being local. The principal reason is that the Kaiparowits Plateau lacks a record of in situ development for the Puebloan occupation like there is for the Virgin region to the west (e.g., McFadden 2016), or the Kayenta region to the south (e.g., Geib 2011; Powell and Smiley 2002; also the Mesa Verde Region to the east). Kaiparowits Puebloan remains are probably no earlier than about AD 1100 (see McFadden 2016 for a detailed review of current chronological data across the entire Grand Staircase-Escalante National Monument, including the Kaiparowits). Prior to this, Fremont populations occupied the area, living in far more dispersed settlements. This Fremont occupation was also once thought to date rather late, roughly contemporaneous with the Puebloan occupation, but the direct dating of Fremont materials from the Escalante River drainage showed that this archaeological expression developed in situ out of preceramic foragers that occupied the area since at least late Basketmaker II times (ca. $200 \mathrm{BC}$ ), with pottery as an addition sometime at around $\mathrm{AD} 600$ or even earlier (e.g., Geib 1996; McFadden 2016).

Migration arguments are most convincing when based on detailed knowledge of the archaeological remains within the purported source area (Cameron 1995; Cameron and Ortman 2017). If Lister and 


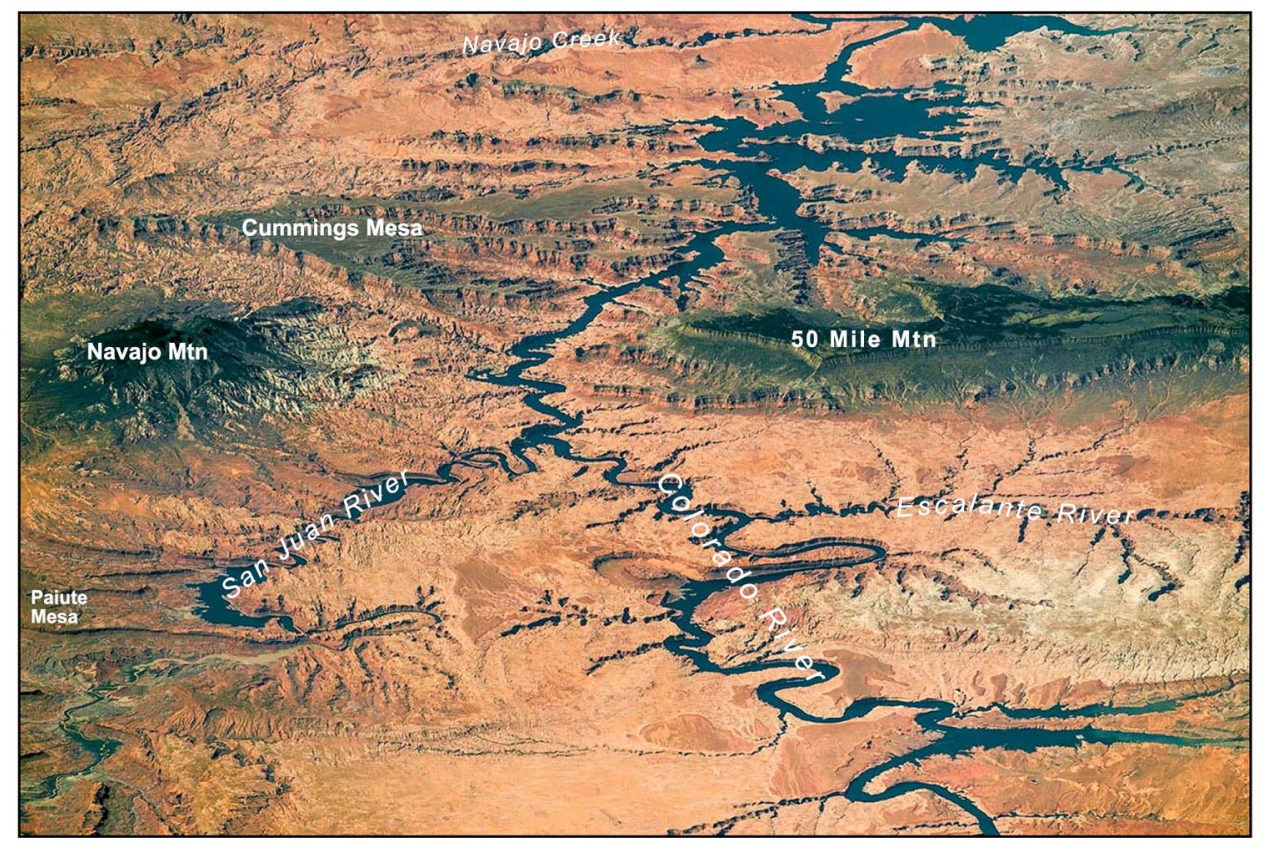

Figure 3. Oblique view from space of Glen Canyon at the confluence of the San Juan and the Colorado Rivers. Only some 10-20 miles of slickrock and the Colorado River separate Kayentan Puebloans living around the foot of Navajo Mountain and on Cummings and Paiute Mesas from the high plateau of Fiftymile Mountain (photo credit: NASA Earth Observatory; astronaut photograph ISSo48-E-73279, acquired September 6, 2016, ISS Expedition 48 crew).

Jennings were right, the closest population source for such a Kayenta migration is the Navajo Mountain area along the Arizona-Utah boarder (Figure 3). The Pueblo II settlements of this northern Kayenta area would have comprised the leading edge of any Kayentan surge to the Kaiparowits. Archaeological research in that area since at least the 1920s, and especially that done by the Museum of Northern Arizona, Northern Arizona University, and the Navajo Tribe since the 1960s, has documented archaeological materials that are typical of those found across the core area of the Kayenta Puebloan cultural tradition (e.g., Ambler et al. 1964; Geib 2011; Geib et al. 1985; Hobler 1974; Lindsay et al. 1968). Indeed, Puebloan settlements of this northern area are an evident result of Pueblo II population expansion from the core Kayenta region further south, especially the Klethla, Long House, and Kayenta Valleys and Black Mesa (Geib 2011:370-373).

So, how do Kaiparowits Puebloan remains compare with those of the Kayentans just to the south? 


\section{Material Culture Comparisons}

\section{Pottery}

I begin with pottery because it has played such importance in previous discussions of cultural identity. Lister based her Kayenta migration argument chiefly on pottery. Lister's ceramic assignments for Fiftymile Mountain (see Fowler and Aikens 1963 and Lister 1964) markedly differ from those I made for Collet Top (Geib et al. 2001). First, we identified completely opposite gray wares. Lister had 95\% Kayenta produced items (i.e., Tusayan Gray Ware, Tsegi Series) on Fiftymile, whereas I have 95\% Virgin Branch ceramics on Collet Top (i.e., Tusayan Gray Ware, Virgin Series and Shinarump). Second, while I found almost no evidence of Kayenta-manufactured whiteware (i.e., Tusayan WhiteWare, Kayenta Series, Figure 4), Lister reported that Tusayan WhiteWare from the Kayenta region made up over half of the white wares from Fiftymile Mountain. Third, I identified virtually all of the red ware pottery on Collet Top as Shinarump. Lister, in contrast,

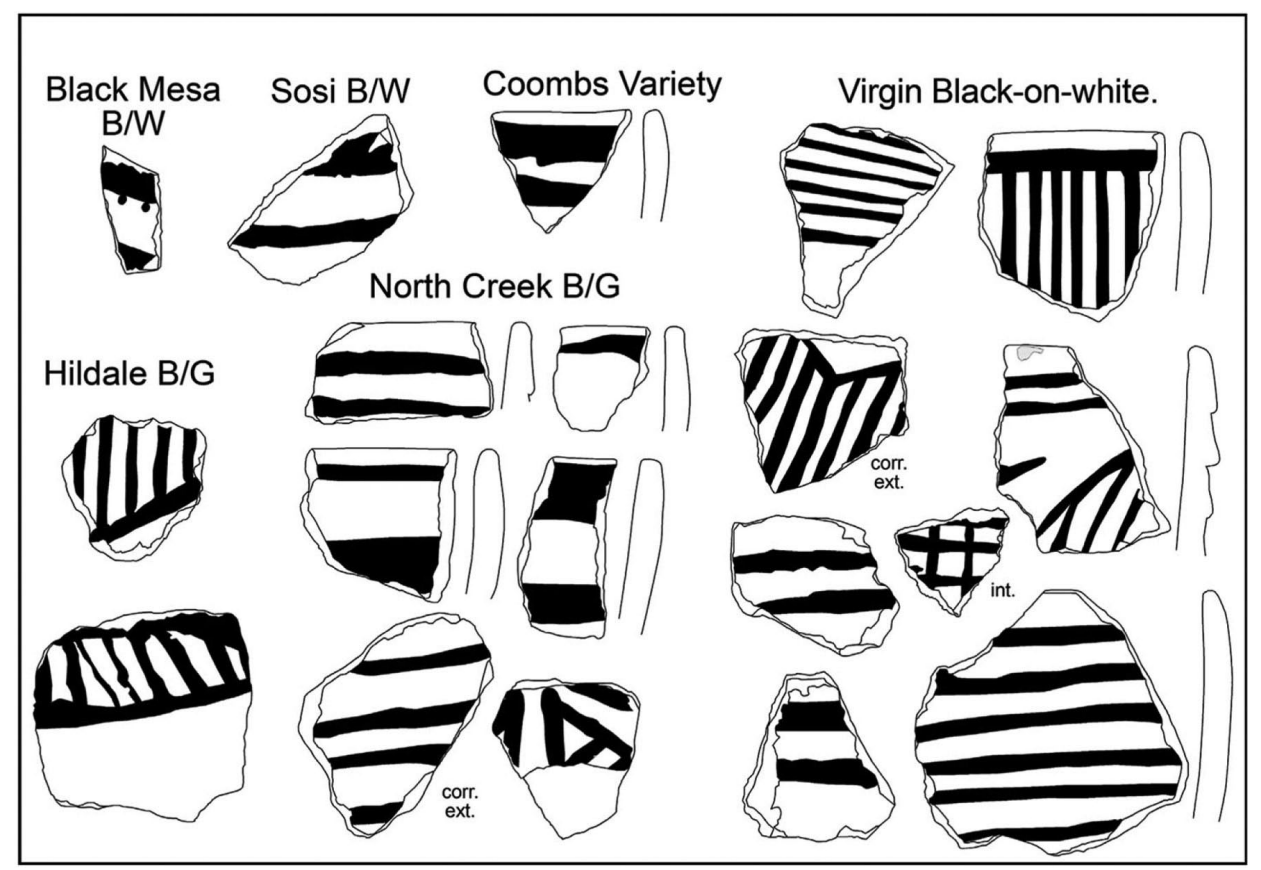

Figure 4. Examples of decorated white ware sherds collected during the Navajo Nation Kaiparowits Plateau survey with nearly all coming from Puebloan sites on Collet Top. 
reported a sizeable proportion of Kayentan red or orange ware on Fiftymile, identified as Tsegi Orange Ware and Middleton Black-on-red and Middleton Polychrome.

On the face of it, two roughly concurrent occupations, as little as 10 miles apart, have two distinct Puebloan ceramic industries and perhaps people: Virgin on Collet Top, Kayenta on Fiftymile. Is this true or are there simply divergent viewpoints on pottery classification? How would I classify many of the sherds that Lister identified as Kayentan? My suspicion is that I would classify many as Virgin wares and types.

My sherd analysis results from Collet Top are actually quite similar to what Gunnerson reported from his Fiftymile Mountain survey: mainly North Creek Gray and Corrugated and North Creek Black-ongray (Gunnerson 1959a), both of which are associated with the Virgin Series. The classification of pottery from sites on Fiftymile Mountain by Gunnerson and Lister, however, reveal markedly different results. For the first University of Utah survey on this highland, Gunnerson (1959a) reported a nearly 10:1 ratio of what he called North Creek Black-on-gray to Kayentan white ware. But Lister's subsequent analysis of excavated sherds from some of Gunnerson's sites as well as sites recorded during a second, more intensive survey (in Fowler and Aikens 1963:43-48, Table 1; Lister 1964) reported that the majority of the decorated white ware sherds belonged to the Kayenta Series of Tusayan White Ware. Lister did, however, identify a large proportion of the white ware sherds as "Southern Utah Series;" part of these are likely comparable with Gunnerson's North Creek Black-on-gray with some comparable to Virgin Black-on-white.

Similarly, much of the sand tempered gray ware pottery from Fiftymile Mountain that Gunnerson identified as North Creek appears to be what Lister later called Kiet Siel Gray. The latter is a distinct Pueblo III Kayenta type that dates from around AD 1200 and later. Gunnerson (1959a:346) admitted that "North Creek Gray sherds show a great deal of variation," including many "rough" sherds with bumpy and pitted surfaces, of the sort that Lister must have classified as Kiet Siel. Gunnerson defined over three times as many North Creek Gray sherds as any other gray ware type, yet Lister actually tallied fewer North Creek Gray than Emery Gray (a Fremont type). In the Kayenta region (and the Glen Canyon lowlands), Kiet Siel Gray is associated with Tusayan and Kayenta Black-on-white and 
contemporaneous late orange wares, but this is evidently not the case on the Kaiparowits Plateau because neither Lister (1964) nor Fowler and Aikens (1963) report these types, making the Kiet Siel identification highly suspect. Unfortunately, I cannot compare corrugated types as readily, as Gunnerson (1959a:345) did not "separate the ... Tusayan and Moenkopi corrugated sherds from ... such variants as North Creek." I do know that Lister placed over 2,800 corrugated sherds under Tusayan GrayWare, Tsegi Series, but identified only 87 as North Creek Corrugated.

My examination of the old Fiftymile Mountain collections at University of Utah in the late 1980s, and also in the field on Fiftymile Mountain during a visit in October of 2003, suggests that Gunnerson's sherd identifications are more correct or at least more similar to how I would classify the material. For example, I did not observe any sherds that I would classify as Kiet Siel Gray, either at University of Utah or in the field, though I did see plenty of plain gray vessel fragments. There are sherds of Kiet Siel Gray in the original Glen Canyon Project collections, such as from the Davis Kiva site (Gunnerson 1959b) of the Escalante River canyon lowlands (in Davis Gulch). I can bolster my concerns over Lister's sherd identifications with an observation made by Beals, Brainerd, and Smith (1945:6), three archaeologists who analyzed thousands of sherds from sites all across the core Kayenta region. They also examined sherds from nearly 100 sites on Fiftymile Mountain and found "marked differences" between the Kaiparowits Plateau pottery and that of the Kayenta region. Even Lister's red ware identifications contradict her conclusion. She identified a full $63 \%$ of the red ware from Fiftymile Mountain as Middleton Black-on-red and Middleton Polychrome. These types now form part of Shinarump Red Ware, whose production zone is in the Virgin area to the north and west of the Colorado River (Allison 2008).

Such disagreements over sherd classification may simply reflect differences in regional geology rather than social distinctions. Presumably, any Puebloan migrant to the Kaiparowits Plateau, no matter where they came from, would use local clay and temper sources. Perhaps for this reason Lister looked past the obvious differences in the clay and temper between the Kaiparowits Plateau pottery and that of the Kayenta region, and saw underlying similarity. But, if the Virgin tradition of pottery production was to temper with sand or crushed 
sandstone then why is the sand-tempered pottery of the Kaiparowits Plateau necessarily derived from the Kayenta region rather than the Virgin region? Why should it be considered Kayenta derived rather than Virgin derived? This calls to mind two critical issues. First, what pottery variables might have real value as social markers rather than monitoring geologic variability? Second, there is a need to look beyond ceramics and consider other aspects of portable material culture or the built environment that could be informative.

For pottery variables of potential social significance, it would be useful to reexamine Fiftymile Mountain sherds and vessels with a discerning eye towards forming techniques, vessel form, design layout, and vessel finishing. Even without reanalysis, the practice of finishing utilitarian vessels without surface corrugation is exceedingly rare in the Kayenta region during the late Pueblo II period. This trait provides a marked contrast between pottery assemblages on Fiftymile Mountain and Pueblo II Kayenta sites on the Rainbow Plateau. For late Pueblo II sites at Navajo Mountain, the ratio of corrugated to plain gray pottery ranges from 66:1-536:1 (based on data from Geib et al. 1985 and Lindsay et al. 1968). Lister's sherd analysis from excavated Fiftymile Mountain sites reveals a 3:1 ratio of corrugated to plain pottery (calculated from data presented in Lister 1964 and Fowler and Aikens 1963). On Collet Top this ratio appears to be almost 1:1. If Kayenta migrants populated Kaiparowits, then they reverted to producing many plain utilitarian vessels, something they had largely stopped doing 50 or more years earlier.

With regard to raw materials used for pottery it is worth noting that vessel fragments on both Collet Top and Fiftymile Mountain include both dark-firing (Shinarump and Virgin Series) and light firing (North Creek) clays. Much of the light colored utility and decorated pottery could have been made from the light-firing Cretaceous clays of the Kaiparowits Plateau, which would indicate production within relatively close proximity to the Puebloan habitations on the plateau. The darker-firing clays, especially those that are vitrified (Shinarump Series), may derive from the clays of the Chinle Formation west of the Cockscomb (Wilson 1985). Thus, some of the Puebloan pottery used in the area probably came from this direction, and perhaps the population did as well. 


\section{Flaked Stone}

Aside from pottery, flaked stone technology also reveals some clear distinctions. Puebloans on Collet Top exploited a variety of brightly colored chert and petrified wood, with some coming from moderate distances to the west and northwest. This was also true of Puebloan sites across other portions of the Kaiparowits Plateau, which usually contained a much higher proportion of brightly colored, high-quality, non-local siliceous stone (Chinle agatized wood, Boulder jasper, and Glen Canyon chert) than sites of other temporal periods. Nearly two-thirds of the Puebloan sites on Collet Top contained material of this sort, and all but two of the structural sites had Chinle agatized wood. All of these materials are imports, with the Chinle wood derived from source areas west of the Kaiparowits Plateau along the Vermilion Cliffs, and the Boulder jasper from the upper Escalante River basin along the foot of Boulder Mountain. The presence of Chinle wood at Kaiparowits Plateau sites indicates a west-to-east movement of material (The Chinle Formation is exposed in portions of the Kayenta region such as in Paiute Canyon and along the lower San Juan river, but the silicified wood in those settings is not the chalcedonic and brightly colored variety, tending to be brown and gray and often somewhat coarse). In this case, rocks do not equal people, but people had to carry that rock and they strongly suggest a direction of travel and interaction westward over the Cockscomb to the Grand Staircase.

This use of high quality and brightly colored siliceous stone is not necessarily unusual. However, the Puebloans on Collet Top commonly heat-treated their stone to improve flaking quality and this is unusual, at least compared to Pueblo II knappers in the Kayenta area. Virtually every Puebloan site on Collet Top had abundant evidence for heat treatment of flaked stone. This was evident in the debitage and the tools (Figure 5 provides an example). In contrast, this technique is largely unknown in the Kayenta region during the Pueblo II period. Examination of over 5000 flakes from seven Pueblo II sites near White Mesa found just 27 cases of heat treatment, less than 1\%. This is typical for the Kayenta region (Bungart et al. 2004). Likewise, Kayenta Puebloan assemblages on the Rainbow Plateau have a near absence of evidence for heat treatment with a representation of just $0.7 \%$ based 


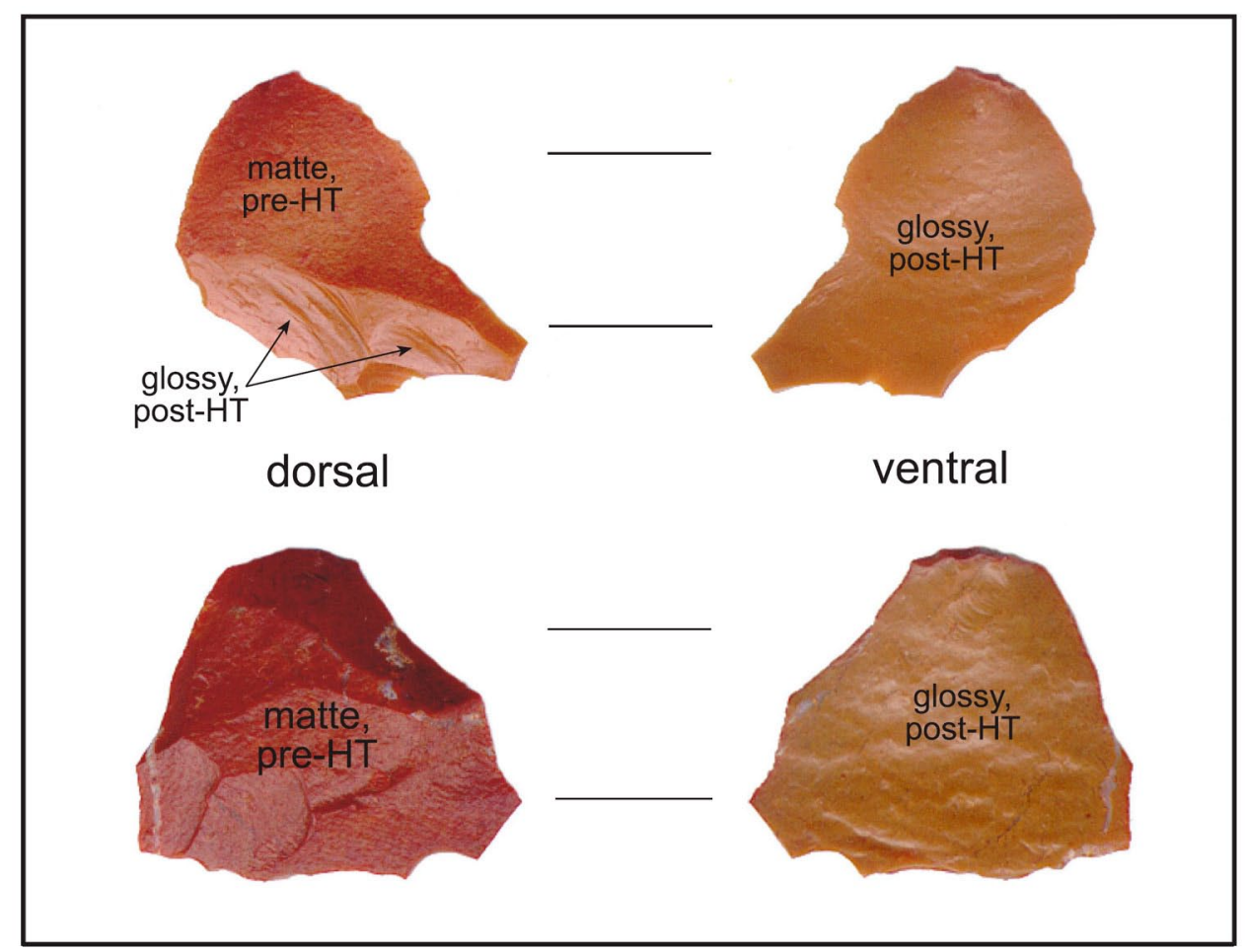

Figure 5. Two biface thinning flakes of Boulder jasper removed from heat-treated tools. The flakes exhibit a contrast in color and luster that is characteristic of heat treatment of this material. Dorsal surfaces are reddened (oxidized) from heating but the ventral surfaces reveal the natural yellowish color of this stone, though with a lustrous and smooth surface, a consequence of the heat treatment. The dorsal surface of the top flake exhibits a few lustrous scars from prior posttreatment removals but the multiple scars on the bottom flake all have a matte surface from roughing out the biface prior to heat treatment. Both flakes come from the trash midden of Gag House, 42KA5435, on Collet Top.

on more than 19,000 flakes (Geib and Warburton $2007: \mathrm{V} \cdot 5 \cdot 32$ ). Of this paltry amount, about half came from post $\mathrm{AD} 1200$ sites, which means even less use of heat treatment during the Pueblo II period.

Another key distinguishing aspect is what the Puebloans on Collet Top did after cooking their siliceous stone: they reduced the material into bifaces using both percussion thinning and pressure flaking. This reduction objective accounts for a large proportion of the flaking debris at Puebloan sites, including habitations. Figure 5 shows two biface thinning flakes from the trash midden of a Puebloan habitation (42KA5435). The flakes were detached after heat-treatment of roughed out bifaces. Biface reduction debris, especially from 
percussion thinning, is seldom found at Pueblo II Kayenta habitations south of the Colorado River, rarely accounting for more than a fraction of an assemblage. For example, at the Pueblo II site of Hammer House on the Rainbow Plateau, biface reduction flakes account for 4 of the 1,535 flakes recovered (0.3\%; Geib and Warburton 2007:Table 5.5)

Flakes from bipolar reduction and, especially, simple unpatterned core reduction account for a large proportion of the debitage at Kayenta habitations (Geib and Warburton 2007; Robins and Warburton 2004). Hard hammer flakes detached from unpatterned cores also occur on Kaiparowits, but they do not dominate the debitage assemblages as in the Kayenta region to the south. The lack of bipolar flakes at Collet Top sites is a significant contrast with Kayenta sites. Bipolar flakes can account for 10\% or more of the debitage at Pueblo II Kayenta habitations. Bipolar and unpatterned core reduction was a key component of Kayenta reduction behavior just as biface reduction was a key component of Puebloan lithic technology on Kaiparowits.

A final contrast is the ratio of flakes to sherds. At Puebloan sites on Collet Top flakes far outnumber sherds, with ratios of 100:1 or more for some sites. At Kayenta habitations sherds almost always outnumber flakes and often do so by ratios greater than 1:1. For example the late Pueblo II site of UT-V-13-19 (NAU) at the foot of Navajo Mountain has a ratio of 4.4:1 (26,003 sherds to 5,864 pieces of debitage; Geib et al. 1985).

The time is ripe for a reappraisal of the Fiftymile Mountain artifact collections. Geologic sources of the raw materials used in lithic production can be informative and indicative of common directions of movement and interaction. But more importantly, where can we find a cultural tradition that could account for the material traits occurring on Kaiparowits Plateau? Emphasis should be placed on modes of production that denote real differences in the ways people learn how to make tools and construct their world.

\section{Architecture}

The built environment can be even more informative of cultural differences than artifacts. A simple example comes from masonry construction. We noted a preponderance of wet-laid masonry on Collet Top: as much as one half masonry to one half mortar $(\sim 50 / 50$ rock and clay). McFadden (2000:182-183) noted a similar construction style 
among granaries in the Collet Canyon drainages. This type of construction method is also characteristic of Fiftymile Mountain. Gunnerson (1959a:335) was the first to report this: "the volume of mortar, in fact, often was about equal to the volume of rock." Fowler and Aikens (1963:5) also report on this phenomenon: "the ratio of stone to clay used in laying up the haphazardly coursed walls appeared to have been about 1:1." This wet-laid construction style, especially the great abundance of mortar, is markedly different from that used by the Kayenta during Pueblo II, who typically used a dry-laid/mudded technique with comparatively sparse amounts of mortar.

More important than how walls were put together is the overall architectural layout of habitations and the types of rooms that are included. The common pattern of late Pueblo II Kayenta habitations is shown in Figure 6 with all drawn to a common scale. The architecture and site layout of these habitations provides a good model of what to expect on Fiftymile Mountain and Collet Top if Kayentans populated the Kaiparowits during late Pueblo II. Figure 6 includes two habitations at the foot of Navajo Mountain just $30 \mathrm{~km}$ southeast of Fiftymile Mountain: Small Jar Pueblo and UT-V-13-19. These sites are evidently

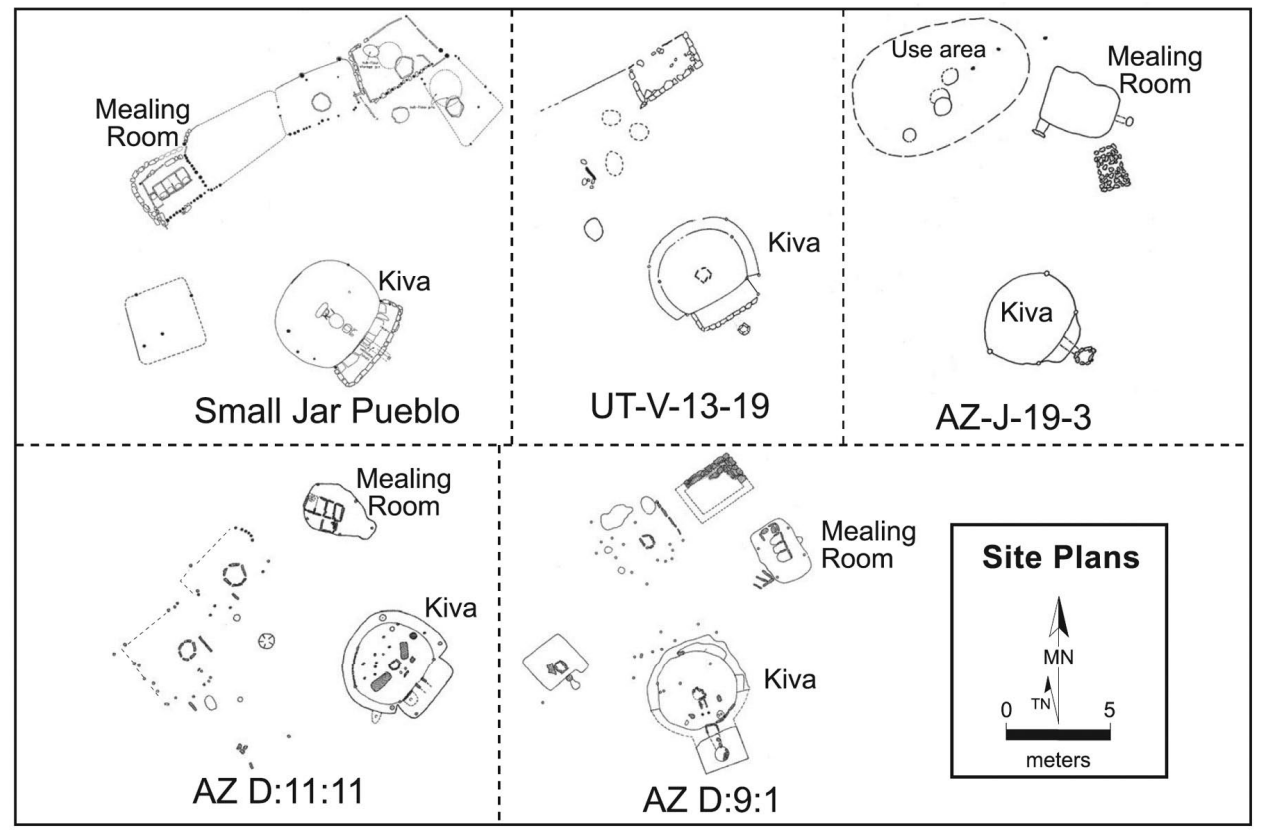

Figure 6. Examples of excavated late Pueblo II habitations from the Kayenta region showing the common layout and structure types that are included (adapted from Geib et al. 1985; Gumerman 1970; Gumerman and Euler 1976; Lindsay et al. 1968; Schroeld 1989: 63). 
part of a late Pueblo II expansion from areas to the south, as there are no middle Pueblo II habitations on the northern part of the Rainbow Plateau around Navajo Mountain (habitations of this time period occur on the southern edge of this plateau close to Paiute Canyon). One typical aspect of a late Pueblo II Kayenta residential site is the presence of a subterranean circular or D-shaped living/ceremonial structure with formal features commonly designated as kivas. There is almost always a mealing room, often in an isolated shallow pithouse; at Small Jar Pueblo the mealing room forms part of the room block. Kivas and mealing rooms are ubiquitous features of Kayenta settlements, even the smallest examples usually have them, and some settlements consists of little more than a kiva, mealing room, and ramada-covered activity areas (e.g., Hammer House [Geib et al. 2007] and AZ-J-19-3 [Schroedl 1989]). Living and storage rooms typically measure about $2.5 \mathrm{~m}$ wide and $2.5-4 \mathrm{~m}$ in length, with the living rooms having slablined hearths that occupy about $1 / 8$ th of the floor space.

Plan maps for most of the excavated sites on Fiftymile Mountain are shown in Figure 7, all drawn to a common scale. Fowler and Aikens (1963:9) saw little similarity between residential sites on Fiftymile Mountain and Virgin sites to the west, such as in the lower Virgin

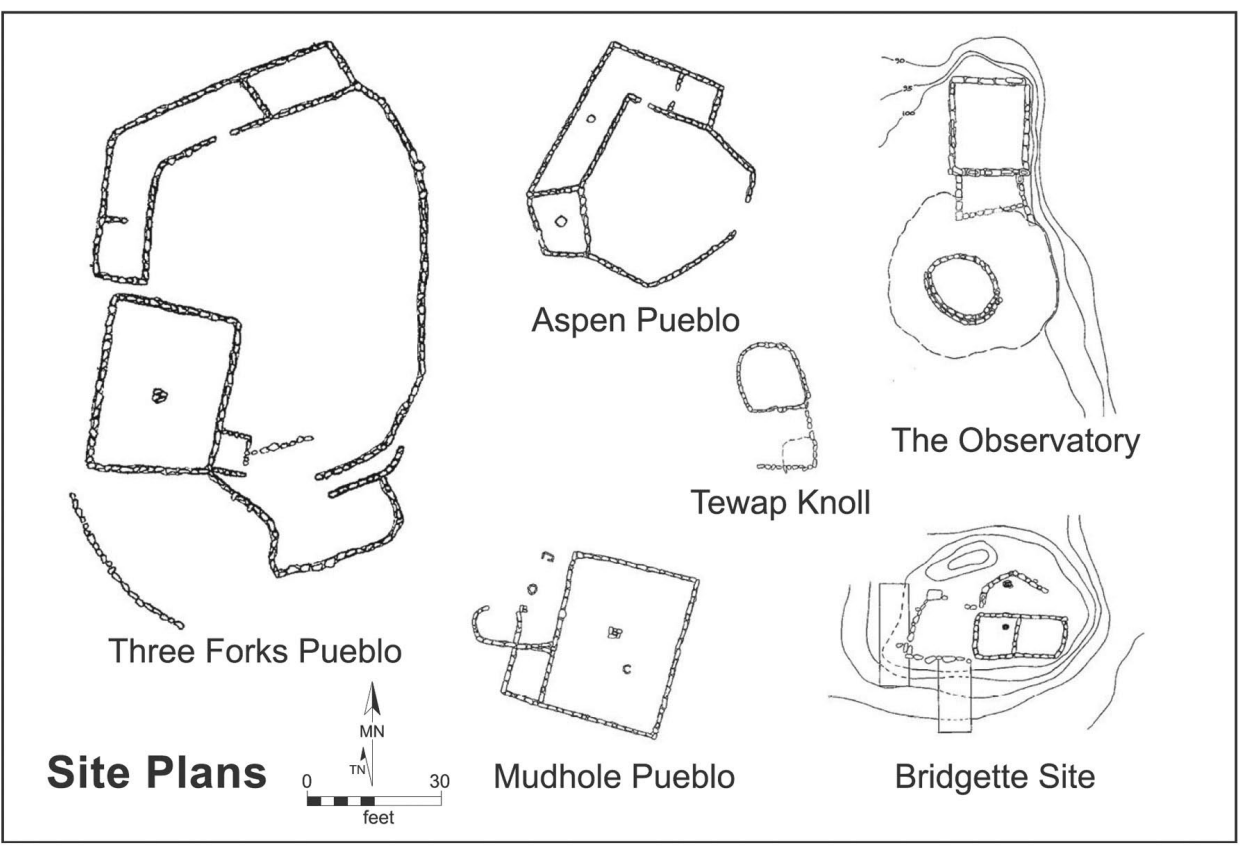

Figure 7. Examples of excavated Puebloan habitations on Fiftymile Mountain (adapted from Fowler and Aikens 1963). 
River valley and Johnson-Paria drainages. None of these have a striking similarity to presumably contemporaneous sites in the Kayenta region, although some, such as the Bridgette Site (42KA346), are quite nondescript. One of the most significant differences is a lack of kivas and mealing rooms at the Fiftymile Mountain sites. These essential components of Kayenta habitations are totally absent. This absence is not a simple result of building settlements on rock prominences that prevented excavation of subterranean rooms. Many ideal sandy rises occur on Fiftymile Mountain that could have accommodated subterranean structures but these locations were not chosen. Moreover, when habitations were situated on rocky prominences in the Kayenta area, such as Pottery Pueblo or Segazlin Mesa, Kayenta builders made cuts into bedrock to accommodate subterranean structures. The $4.6 \mathrm{~m}$ diameter circular Structure 3 at The Observatory (42KA368) might be construed as an attempt to make a kiva-like surface room where excavation was difficult. This seems a stretch however, because there are none of the usual Kayenta kiva floor features in this structure. Indeed, the report lists no floor features at all (Fowler and Aikens 1963:34).

The two plaza sites on Fiftymile Mountain, Aspen Pueblo and Three Forks Pueblo, look nothing like sites excavated in the Kayenta region. Structure 1 of Three Forks Pueblo is 2-3 times larger than Kayenta structures, measuring 6.4 by $10.1 \mathrm{~m}$. This overly large structure size occurs at other sites such as Mudhole Pueblo (42KA354), where Structure 1 measures 6.4 by $9.1 \mathrm{~m}$, and The Observatory, where Structure 1 measures 6.1 by $7.6 \mathrm{~m}$. Quite unusually, many of the structures lack hearths, and when present they are small basins rather than slab-lined affairs. The two central roof support pillars seen in the large rooms at Three Forks Pueblo and Mudhole Pueblo are unprecedented in the Kayenta region. Little wonder that McFadden (2000:197) described the Fiftymile Mountain architecture and site type patterns as "distinctive-they are not known anywhere else in the southwest.”

\section{Discussion and Conclusion}

If Kayentans from south of the Colorado River migrated to Kaiparowits Plateau, then why did they abandon their late Pueblo II tradition of making corrugated pots and their common lithic reduction strategies of detaching expedient flakes from simple, unprepared cores 
and bipolar cores? Why the high proportions of plain gray jars and lithic assemblages dominated by bifacial reduction debris on the Kaiparowits Plateau? Since kivas and mealing rooms were such essential elements at Kayenta habitations, why are these absent from the Kaiparowits Plateau? These differences are difficult to reconcile with the Kayenta migration hypothesis. A few aspects might differ, something often found in migrant populations because they rarely reflect the full social complement of the home community (e.g., Anthony 1990). The suite of traits on Kaiparowits cannot be traced to the core Kayenta region and it seems unlikely that simply crossing a river and climbing a mesa would result in such multifaceted change.

But if not Kayenta migrants, then who populated the Kaiparowits? I believe that Gunnison was essentially correct. Puebloans expanded from the west and southwest, originating from the Grand Staircase to the Paria and Kaibab Plateau. I use the term Virgin for this Puebloan population, but readily admit that an expert in far western Virgin archaeology might not agree with such a label.

Naming for the sake of naming is not the point. Rather, I seek to understand how Puebloan communities became established on the Kaiparowits in a region that lacked a local developmental trajectory for such communities. The direction of movement for such a population is important for understanding what technologies and social organization they might have brought with them and how these might have changed to fit the new setting, and what the nature of social interactions might have been with in situ Fremont groups. The "push and pull" mechanisms (see Anthony 1990) for migration may have varied depending upon the source region of the Puebloan population. If the terms Kayenta and Virgin carry too much baggage and interfere with productive archaeological debate, then this entire discussion could be rephrased by substituting neutral geographic or directional terms for the populations involved.

To address the issue of Puebloan migrants to the Kaiparowits Plateau we must range widely across this plateau and beyond to the Grand Staircase and the Escalante desert. As such, I appreciated the original boundaries of Grand Staircase-Escalante National Monument, which were drawn at a scale conducive to investigating my question. Future research into this issue would benefit from careful restudy of the 196os Fiftymile Mountain survey and excavation collections and notes housed at the Natural History Museum of Utah. Old collections 
invariably have some limitations, so ultimately new field research should be conducted, both survey and excavation, with the latter likely to provide a wider assortment of pertinent data.

Acknowledgments - I thank Karen Harry and Sachiko Sakai for organizing an SAA symposium in honor of Margaret Lyneis and for inviting me to participate. It was my pleasure to have collaborated with Margaret on a study of Fremont pottery to better understand its production and exchange in south-central Utah. Margaret provided the petrographic expertise, a technical skill she picked up later in life. That study illustrates her scholarship outside the Virgin area, work that built upon her long standing interest in pottery. I also want to acknowledge the help of Jim Collette who worked on an earlier version of this paper with me and whom also accompanied me on a hike to Fiftymile Mountain in October of 2003 to explore this highland and visit the sites excavated by Fowler and Aikens. We would be more than happy to return the lost chaining pin found at Three Forks Pueblo to either Don Fowler or Mel Aikens if they can identify it. I also appreciate the helpful comments of two reviewers: Helen Fairley and one that remains anonymous. Thanks also to Danny Perez for translating the abstract into Spanish.

Disclosures - No potential conflict of interest was reported by the author.

\section{References}

Aikens, C. Melvin

1962 The Archaeology of the Kaiparowits Plateau, Southeastern Utah. Unpublished Master's thesis, University of Chicago, Chicago.

1963 Appendix II: Kaiparowits Survey, 1961. In 1961 Excavations, Kaiparowits Plateau, Utah, edited by Don D. Fowler and C. Melvin Aikens, pp. 70-10o. Anthropological Papers No. 66. University of Utah Press, Salt Lake City.

Allison, James R.

2008 Shinarump Red Ware and Other Red Ware Pottery: North and West of the Colorado River. Pottery Southwest 27(1):21-34.

Ambler, J.R., A.J. Lindsay, and M.A. Stein

1964 Survey and Excavations on Cummings Mesa, Arizona and Utah, 196o1961. Museum of Northern Arizona Bulletin No. 42. Northern Arizona Society of Science and Art, Flagstaff.

Anthony, David W.

1990 Migration in Archeology: The Baby and the Bathwater. American Anthropologist 92:895-914.

Beals, R.L., G.W. Brainerd, and W. Smith

1945 Archaeological Studies in Northeast Arizona: A Report on the Archaeological Work of the Rainbow Bridge-Monument Valley Expedition. 
Publications in American Archaeology and Ethnology Vol. 44, No. 1. University of California Press, Berkeley and Los Angeles.

Bungart, Peter B., Jim Collette, and Kim Spurr

2004 A Better Road Ahead: Archaeological Excavations along Navajo Route 21 near White Mesa, Arizona. Navajo Nation Archaeology Department Report No. 01-237. Navajo Nation Historic Preservation Department, Window Rock, Arizona.

Cameron, Catherine M.

1995 Migration and the Movement of Southwestern Peoples. Journal of Anthropological Archaeology 14 (2):104-124.

Cameron, Catherine M. and Scott G. Ortman

2017 Movement and Migration. In The Oxford Handbook of Southwest Archaeology, edited by Barbara Mills and Severin Fowles, pp. 715-728. Oxford University Press, New York.

Fairley, Helen

1997 Cultural Boundary Dynamics on the Northern Kayenta Frontier: A View from Glen Canyon and Eastern Grand Canyon. Paper presented in the symposium "The Glen Canyon Project and After: Archaeology in 'The Place No One Knew,' 1957-1997" at the 62nd Annual Meeting of the Society for American Archaeology, Nashville.

Fowler, Don D., and C. Melvin Aikens

19631961 Excavations, Kaiparowits Plateau, Utah. Anthropological Papers No. 66. University of Utah Press, Salt Lake City.

Geib, Phil R.

1996 Glen Canyon Revisited. Anthropological Paper No. 119. University of Utah Press, Salt Lake City.

2011 Foragers and Farmers of the Northern Kayenta Region. Excavations along the Navajo Mountain Road. University of Utah Press, Salt Lake City.

Geib, Phil R., and Miranda Warburton

2007 Patterns in Stone Tool Raw Materials, Production, and Use: Analysis of the N16 Lithic Artifacts. In Prehistory of the Northern Kayenta Anasazi Region: Archaeological Excavations along the Navajo Mountain Road. Volume V, Analyses and Interpretation, edited by Phil R. Geib and Kimberly Spurr, pp. V.5.1-V.5.90. Navajo Nation Archaeological Department Report 02-48, Window Rock.

Geib, Phil R., Kimberly Spurr and Jim Collette

2007 Prehistory of the Northern Kayenta Anasazi Region: Archaeological Excavations along the Navajo Mountain Road. 5 Volumes. Navajo Nation Archaeological Department Report 02-48,Window Rock.

Geib, Phil R., J. Richard Ambler, and Martha M. Callahan

1985 Archaeological Investigations near Rainbow City, Navajo Mountain, Utah. Northern Arizona University Archaeological Report No. 576. Flagstaff. 
Geib, P.R, K. Spurr, and J. Collette

2001 Kaibabitsinüngwü: An Archaeological Sample Survey of the Kaiparowits Plateau. Cultural Resource Series No. 25, Bureau of Land Management, Salt Lake City.

Gumerman, George J.

1970 Black Mesa: Survey and Excavation in Northeastern Arizona, 1968. Prescott College Studies in Anthropology 2, Prescott College Press, Prescott.

Gumerman, George J., and Robert C. Euler (editors)

1976 Papers on the Archaeology of Black Mesa, Arizona. Southern Illinois University Press, Carbondale.

Gunnerson, James H.

1959a Archaeological Survey of the Kaiparowits Plateau. In The Glen Canyon Archaeological Survey, edited by Don D. Fowler, James H. Gunnerson, Jesse D. Jennings, Richard H. Lister, Dee Ann Suhm, and T. Weller, pp. 318-471. Anthropological Papers No. 39, Part II. University of Utah Press, Salt Lake City.

1959b 1957 Excavations, Glen Canyon Area. Anthropological Papers No. 43. University of Utah Press, Salt Lake City.

Hobler, Phillip M.

1974 The Late Survival of Pithouse Architecture in the Kayenta Anasazi Area. Southwestern Lore 40(2):1- 44.

Jennings, Jesse. D.

1966 Glen Canyon: A Summary. Anthropological Papers No. 81. University of Utah Press, Salt Lake City.

Kluckhorn, Clyde

1933 Beyond the Rainbow. Christopher Publishing House, Boston.

Lindsay, A.J. , J. Richard Ambler, Mary Ann Stein, and Phillip M. Hobler

1968 Survey and Excavation North and East of Navajo Mountain, Utah 19591962. Museum of Northern Arizona Bulletin No. 45. Northern Arizona Society of Science and Art, Flagstaff.

Lister, Florence C.

1964 Kaiparowits Plateau and Glen Canyon Prehistory: An Interpretation Based on Ceramics. Anthropological Papers No. 71. University of Utah Press, Salt Lake City.

McFadden, Douglas A.

2000 Formative Chronology and Site Distribution on the Grand StaircaseEscalante National Monument. Draft report on file, Bureau of Land Management, Kanab Resource District, Cedar City.

2016 Formative Chronology and Site Distribution on the Grand StaircaseEscalante National Monument: A Research Reference. Utah Cultural Resource Series No. 28, Bureau of Land Management, Salt Lake City. 
Powell, Shirley, and Francis E. Smiley (editors)

2002 Prehistoric Culture Change on the Colorado Plateau: Ten Thousand Years on Black Mesa. University of Arizona Press, Tucson.

Robins, Michael R., and Miranda Warburton

2004 N21 Lithic Analysis. In A Better Road Ahead: Archaeological Excavations along Navajo Route 21 near White Mesa, Arizona, edited by Peter B. Bungart, Jim Collette, and Kim Spurr, Chapter 23. Navajo Nation Archaeology Department Report No. 01-237. Navajo Nation Historic Preservation Department, Window Rock, Arizona.

Schroedl, Alan R. (editor)

1989 Kayenta Anasazi Archeology and Navajo Ethnohistory on the Northwestern Shonto Plateau: The N-16 Project. P-III Associates, Salt Lake City.

Wilson, Dean

1985 Analysis of Ceramics Recovered During the Vermilion Cliffs Project. In Archaeological Test Excavations at the Energy Fuels Nuclear, Inc., Vermilion Cliffs Project, Kane County, Utah, edited by Deborah H. Westfall, pp. 114-132. Abajo Archaeology, Bluff, Utah. 